\title{
Problems and Resolutions in the Practice of Project Teaching in Higher Vocational Schools
}

\author{
Zhichong Sheng \& Jianhua Tan \\ Nanjing Institute of Industry Technology, Nanjing 210046, China \\ E-mail: tanjh@niit.edu.cn
}

Received: April 29, 2011 Accepted: June 3, $2011 \quad$ Published: November 1, 2011

doi:10.5539/ies.v4n4p80 URL: http://dx.doi.org/10.5539/ies.v4n4p80

\begin{abstract}
Recently, there has been a hot discussion on project teaching theory among many higher vocational schools; however the practice of project teaching is still in the beginning period. Hence, many problems appear in project lead. This paper aims to analyze the existing problems in the practice of project teaching and also raise some resolutions.

Keywords: Higher vocational schools, Project teaching method, Problems, Resolutions

The developing direction and training objective of higher vocational education is job-orientated and service-aimed to cultivate skilled talents that society needs. Therefore, higher vocational education should fully reflect the characteristics of career and job. Its cultivation objective and orientation should fit the requirements for talents. However, the common phenomenon is that there is a quite many students could not find job fitting for their majors when finish school education. It is true that this phenomenon is related with market demands, but the key is that the talents trained by many schools cannot satisfy the market's requirements. How to achieve the training object of higher vocation education is an issue that deserves us reflection. There is no doubt that new teaching ideas and teaching methods should be carried, among which project teaching method has displayed obvious better performance in training the students' comprehensive quality and career ability. Since the study of teaching method should take teaching method and features of its application filed into consideration, when it comes to higher vocational education, features of project teaching method and higher vocational education should be considered.
\end{abstract}

\section{Project Teaching Method and Its Characteristics}

Compared with traditional teaching method, project teaching method has the following unique characteristics.

\subsection{Focus on Knowledge Application}

Project teaching method has effectively built the connection between classroom and society as decided by its nature. A project is a mission that designed by learned theoretical knowledge. When doing the project, students are required to solve real problems with their learned theory, which will level their theory application ability.

\subsection{Focus on Study Initiative}

The project teaching method requires the students to collect information independently or by group; they are asked to design program and put it into effect and take part in the final project assessment. Thus, students become the subject of study, which will fully arouse the student's learning initiative. Consequently, teacher's role is changing from a theory implanter to a study guide.

\subsection{Focus on Exploration}

The students are learning know knowledge by their exploration, rather than just get answers from teacher. The project requires the students to make use of their creative ability to explore.

\subsection{Focus on Training the Students' Comprehensive Quality}

The project is a kind of mission that has certain realistic significance. Therefore, during the project the students can practice their ability to fuse into the society, such as the ability to practice, observe, self-study, analyze, manage, adapt and communicate.

\subsection{Focus on Mutual Cooperation}

Since a comparatively complicated project needs the students to cooperate by group, group members can inspire and 
complement each other. The cooperation ability is one of the necessary qualities of modern business man and project teaching method is helpful to cultivate such quality.

\section{Project Teaching Method and Higher Vocational Education}

As project teaching method is in consistence with the training objectives of higher vocational education, its application in higher vocational education has huge room.

2.1 Project teaching method focuses on training the ability of application which is in consistence with higher education's aim to cultivate talents with applied competence. Project teaching method lays emphasis on cultivating students' application ability, which narrows the differences between student's ability and enterprise's requirements and will benefit the students to better accustom production line and make them know the theory and also know how to operate.

2.2 Project teaching method pays attention on cultivating comprehensive ability and vocational education to train first line talents for production, management and service. It creates working environment for students and can broaden the students' horizon and practice their application ability and also is helpful to cultivate their sense of cooperation and career moral. In a word, project teaching method can help the students to adapt to their jobs after graduation.

\section{Problems in the Practice of Project Teaching Method in Higher Vocational Education}

At present, a lot of higher vocational schools have understood the importance of project teaching method. Project teaching method can be applied to many areas. Normally, project teaching method is adopted in specialized courses and training courses. However, project teaching method is still in the beginning period and there are some problems in the application of project teaching method in some higher vocational schools.

\subsection{Cognition Problems}

3.1.1 Antithesis of project teaching method and traditional teaching method. The manifestation of antithesis of project teaching method and traditional teaching method is replacing traditional teaching method with project teaching method or giving up traditional teaching method in project teaching. The two teaching methods have unique advantages. Project teaching method focuses on the cultivation of ability, while traditional teaching method emphasize on the master of theory knowledge. Higher vocational schools should combine the two together, but not settle them against each other.

3.1.2 Treating project teaching method in a mechanical way. Papers on how to use project teaching method always hold that students must be divided into different groups, there should be a certain number in each group, the application process must be divided into a certain number steps and how to assess the result. As far as my concerned, the summary of experience and the exploration of theory should not be done mechanically.

\subsection{Problems in Practice}

\subsubsection{Problems in preparing period of project teaching}

Firstly, many higher vocational schools are in lack of standards. Basically speaking, a number of teachers are in the progress of exploration. As for schools, they did not pay enough attention and did not have standards, which cannot guarantee the teaching quality and not good for popularizing the teaching method and summarizing teaching experience. Secondly, in the teaching period, guidance for students is in sufficiency. Finish a project does not only need knowledge and skills, but also needs proper methods. Ignoring the training of method is not good for students to give play their creative ability and not good to cultivate their comprehensive quality and the undergoing of project teaching method. Thirdly, many higher vocational schools did not provide sufficient materials and methods for the students in the practice of project teaching method, and they did not have matching textbook for project teaching. The resources of project teaching method mainly include library, internet, multi-media power point, laboratory, file of passed project and results exhibition and etc. Since such resources are far from enough, it affects, to a great extent, the project's quality and the students creative ability. Form the angle of textbook, the content and system of textbook are not in consistence with project teaching.

\subsubsection{Problems in the application of project}

On the one side, some projects are in lack of horizontal correlation and integrity. Some projects can be solved by the knowledge of one course; thus they are in lack of theory integrity. While some projects are not as real as production and management and they are not true project teaching. On the other side, in the progress of project teaching, there is no detailed settlement to actualize the training objective of comprehensive quality. Project teaching method cannot automatically train the students' comprehensive ability and they need other peoples' guidance as well. For instance, introduction of methodology, exhibition and macro direction can be used to train the students' creative ability. 
3.2.3 Problems in assessment of project teaching. Firstly, some higher vocational schools have not established teaching file and they also ignored to collect and display the project's results. Doing a project needs all group members overall hard work and exploration. With the aim to learn from other people's advantages, the summary of projects plays an importance role. Establishing project teaching file is good for accumulating teaching methods, resources and displaying project results can encourage the students to innovate. Secondly, many project assessments are in lack of referenced criteria. Hence, the authenticity of such assessments cannot be guaranteed. At present, the main project assessments way is the integration self-judgment, mutual judgment and teachers' judgment. There are many criteria for project assessment, such as preparation of documents, master of basic knowledge, application of knowledge, team-work, project report and so on. However, problems such as how to apply these standards and how to guarantee the authentic of the assessment, and which standards are key standards need further exploration.

\section{How to Solve the Problems in the Application of Project Teaching}

Three transitions must be done in the practice of project teaching. Namely, the transition from teacher-centered to students-centered, the transition from textbook centered to project-centered and the transition from classroom centered to laboratory-centered. For the above problems existing in the practice of projecting teaching, the author puts forward some resolutions as follows.

First, project teaching is not against traditional teaching. They are supposed to complement each other. The objective of traditional teaching is passing on knowledge and skills while the objective of project teaching is to apply skills and knowledge. As a consequence, project teaching should not give up traditional teaching and ignore basic knowledge. What is right is to classify reasonably knowledge and skills. The knowledge and skills that students can learn by themselves could be included into project. As for the knowledge and skills that are difficult for students to learn could be taught by teachers in advance and then consolidate them by project teaching method.

Second, project teaching method should be treated in a flexible way. The key is to classify the essence and form of project teaching method. Its essence is to cultivate the student's application ability and comprehensive ability and its form is actually the methods adopted to train the student's application ability and comprehensive ability. Teaching activities must be done with the aim to actualize teaching essence. They can be flexible.

Third, higher vocational schools must standardize project teaching method to guarantee teaching quality. Specific standardization methods include launching activities to summarize project teaching, carrying out discussion activities to improve the teachers' teaching ability; making rules to carry out project teaching method, such as application, approval and assessment system so as to manage and supervise project teaching effectively; develop and build project teaching resources; considering project teaching as a part of course establishment and to make full use of project teaching method in higher vocational education.

Fourth, before project teaching, lectures and displays can be used to teach the students on methodology. Training methods in higher vocational education includes thinking training and skill training. The skill feature of project teaching should be highlighted and also its application feature.

Fifth, teaching resources are the key guarantee for achieving study task, which requires the teachers creation and coordination. Teaching resources include hard resources and soft resources. Its realization requires school's overall scheme. It is necessary for teachers to provide a part of teaching resources, such as making multi-media power point, writing and editing teaching materials and even textbooks.

Sixth, a good project is one that is closely related with social development and market requirement, namely a certain extent of integrity, which can guarantee the students to train their application ability and comprehensive ability. Since doing a project needs knowledge on many majors, it is necessary to integrate some courses to let the students learn from solving problems. Project teaching should be done in accordance with the school and the student's reality.

Seventh, when adopting project teaching, it is necessary to settle detailed links for the training of comprehensive ability. When practicing the comprehensive criteria, the following should be paid to attention: the corresponding plan for project teaching, content needs priority attention, contents needs to be highlighted during summary and contents needs to be included in project assessment.

Eighth, the summary of project should include many aspects, for instance summary of idea, technique and methods. Higher vocational schools should make full use of project results, file them together and exhibit some good results. It is helpful to encourage the students to be innovative and build teaching materials and to achieve combination of production and study.

Ninth, assessment of project should be focused on the master of theory knowledge, application ability, methodology and cooperation ability. Assessment methods can be diverse and flexible and can include some written content. How to put the standards into practice and how to make them accurate and just still needs us discussion. 
Project teaching method has just been applied to teaching activities; however, from the angle of teaching results it is more effective than traditional teaching method and case teaching. It can narrow the gap between theory and actual application. Basing on practice experience, we will keep on perfecting project teaching method and make higher vocational education accustomed to market requirements so as to achieve the goal to train practicable talents.

\section{References}

Changliang, Yang. (2006). A Study on the Application of Project Courses of Vocational Education. Communication of Vocational Education, 3

Guoqing, Xu.(2006). Basic Theory of Project Courses. Vocational \& Technical Education Forum, 8

Minquan, Wang and Xiaoyan, Mei. (2007) Exploration and Practice of Project Teaching in Higher Vocational Education. Vocational Education Research, 10

Qingbin, Jiang \& Guoqing, Xu. (2005).Discussion on Project Courses of Vocational Education with a Base of Working Task. Vocational and Technical Education, 22 